\title{
A New Genus of the Order Actinomycetales, Couchioplanes gen. nov., with Descriptions of Couchioplanes caeruleus (Horan and Brodsky 1986) comb. nov. and Couchioplanes caeruleus subsp. azureus subsp. nov.
}

\author{
TOMOHIKO TAMURA, ${ }^{1 *}$ YUMIKO NAKAGAITO, ${ }^{1}$ TADASHI NISHII, ${ }^{1}$ TORU HASEGAWA, ${ }^{1}$ \\ ERKO STACKEBRANDT, ${ }^{2}$ AND AKIRA YOKOTA ${ }^{1}$ \\ Institute for Fermentation, Osaka, Yodogawa-ku, Osaka 532, Japan, ${ }^{1}$ and Deutsche Sammlung von Mikroorganismen \\ und Zellkulturen GmbH, 38124 Braunschweig, Germany ${ }^{2}$
}

\begin{abstract}
During our taxonomic study of motile actinomycetes, soil isolate RA 335 was found to form a blue substrate mycelium and aerial mycelia with motile arthrospores and to have lysine as the cell wall diamino acid. Actinoplanes caeruleus IFO $13939^{\mathrm{T}}$ ( $\mathrm{T}=$ type strain) and "Actinoplanes azureus" IFO $13993^{\mathrm{T}}$ are known to have the same characteristics. Therefore, the taxonomic position of these three strains was studied. Aerial mycelia of these strains fragmented during the growth cycle and produced motile spores arranged in chains within the mycelia. Sporangia were not observed. The strains contained menaquinone $9\left(\mathrm{H}_{4}\right)$, had guanine-plus-cytosine contents of 69.9 to $72.1 \mathrm{~mol} \%$, and had D-glutamic acid, D- and L-serine, glycine, L-alanine, and L-lysine as cell wall amino acids (type $A 3 \alpha$ ). The taxonomic characteristics of these strains differ from those of the previously described motile actinomycetes. On the basis of morphological, physiological, and chemotaxonomic data and the results of DNA-DNA hybridization and comparative 16S rRNA studies, we propose a new genus, Couchioplanes, for these organisms. The type species is Couchioplanes caeruleus comb. nov. (type strain, IFO 13939), which is divided into two subspecies, Couchioplanes caeruleus subsp. caeruleus subsp. nov. (type strain, IFO 13939) for $A$. caeruleus IFO $13939^{\text {T }}$ and strain RA 335 and Couchioplanes caeruleus subsp. azureus (type strain, IFO 13993) for "A. azureus" IFO 13993 ".
\end{abstract}

During our taxonomic study of motile actinomycetes isolated from natural sources, we found that strain RA 335, which was isolated from soil in Japan, produces zoospores, has L-lysine in its cell wall, and forms mature mycelium that changes from orange to dark blue. Actinoplanes caeruleus, as described by Horan and Brodsky (9), and "Actinoplanes azureus" (2) are known to have the same characteristics. Actinoplanes species other than Actinoplanes caeruleus contain mesodiaminopimelic acid in their cell walls (29), but Actinoplanes caeruleus and "Actinoplanes azureus" have lysine instead of meso-diaminopimelic acid in their cell walls (9). Therefore, Stackebrandt and Kroppenstedt (24) and Goodfellow et al. (4) insisted that Actinoplanes caeruleus should not be included in the genus Actinoplanes. Thus, the taxonomic position of Actinoplanes caeruleus and "Actinoplanes azureus" has remained uncertain.

We studied the taxonomic position of these two species and isolate RA 335 and found that these organisms are motile arthrospore-bearing actinomycetes that contain menaquinone $9\left(\mathrm{H}_{4}\right)\left[\mathrm{MK}-9\left(\mathrm{H}_{4}\right)\right]$ and have lysine and glycine in their cell walls (wall chemotype VI) and therefore differ from the previously described members of the motile arthrospore-bearing actinomycete genera Sporichthya, Actinosynnema, Actinokineospora, and Catenuloplanes (31).

In this paper we describe the characterization and classification of Actinoplanes caeruleus, "Actinoplanes azureus," and isolate RA 335, and we propose that these organisms should be included in a new genus, Couchioplanes, as members of Couchioplanes caeruleus comb. nov., which is divided into two

* Corresponding author. Mailing address: Institute for Fermentation, Osaka, 17-85, Juso-honmachi 2-chome, Yodogawa-ku, Osaka 532, Japan. Phone: 06-300-6555. Fax: 06-300-6814. subspecies, Couchioplanes caeruleus subsp. caeruleus subsp. nov. and Couchioplanes caeruleus subsp. azureus subsp. nov.

\section{MATERIALS AND METHODS}

Microorganisms and culture conditions. The following strains were used: Actinoplanes caeruleus IFO $13939^{\mathbf{T}}$ (IFO, Institute for Fermentation, Osaka, Japan) ( $\mathrm{T}=$ type strain), "Actinoplanes azureus" IFO 13993", and strain RA 335. Strain RA 335 was isolated from soil in Shiga Prefecture, Japan, on medium containing $1.0 \%$ soluble starch, $0.1 \%$ casein, $0.05 \%$ $\mathrm{K}_{2} \mathrm{HPO}_{4}$, and $1.5 \%$ agar (pH 7.0 to 7.5 ) and supplemented with $25 \mu \mathrm{g}$ of cefsulodin per $\mathrm{ml}$ and $6.25 \mu \mathrm{g}$ of kabicidin per $\mathrm{ml}$. Catenuloplanes japonicus IFO $14176^{T}$, IFO 14177 , and RA 330 (31) were used as reference strains for the DNA relatedness study and for a comparison of $16 \mathrm{~S}$ rRNA sequences.

Cultural observations. Cultural characteristics were recorded after 14 days of incubation at $28^{\circ} \mathrm{C}$ by using the International Streptomyces Project (ISP) method (23). Colors were described in common terminology, but exact colors were determined by comparison with color chips from the Color Harmony Manual (2a).

Morphological and physiological characterization. Morphological features were observed on HV agar (7), and physiological features were observed on media commonly used for identification of members of the order Actinomycetales (23). Motility was observed with a light microscope by using cells in the logarithmic growth phase grown on HV agar or cells in the stationary phase after incubation at $28^{\circ} \mathrm{C}$ for $1 \mathrm{~h}$ in $0.01 \mathrm{M}$ phosphate buffer (pH 7.0) containing $10 \%$ soil extract. Flagellation was observed with a model JEM-1200EX transmission electron microscope (JEOL, Ltd., Tokyo, Japan) after shadowing with platinum-palladium. Cultures grown on $\mathrm{HV}$ agar for 14 days at $28^{\circ} \mathrm{C}$ were observed with a scanning electron 

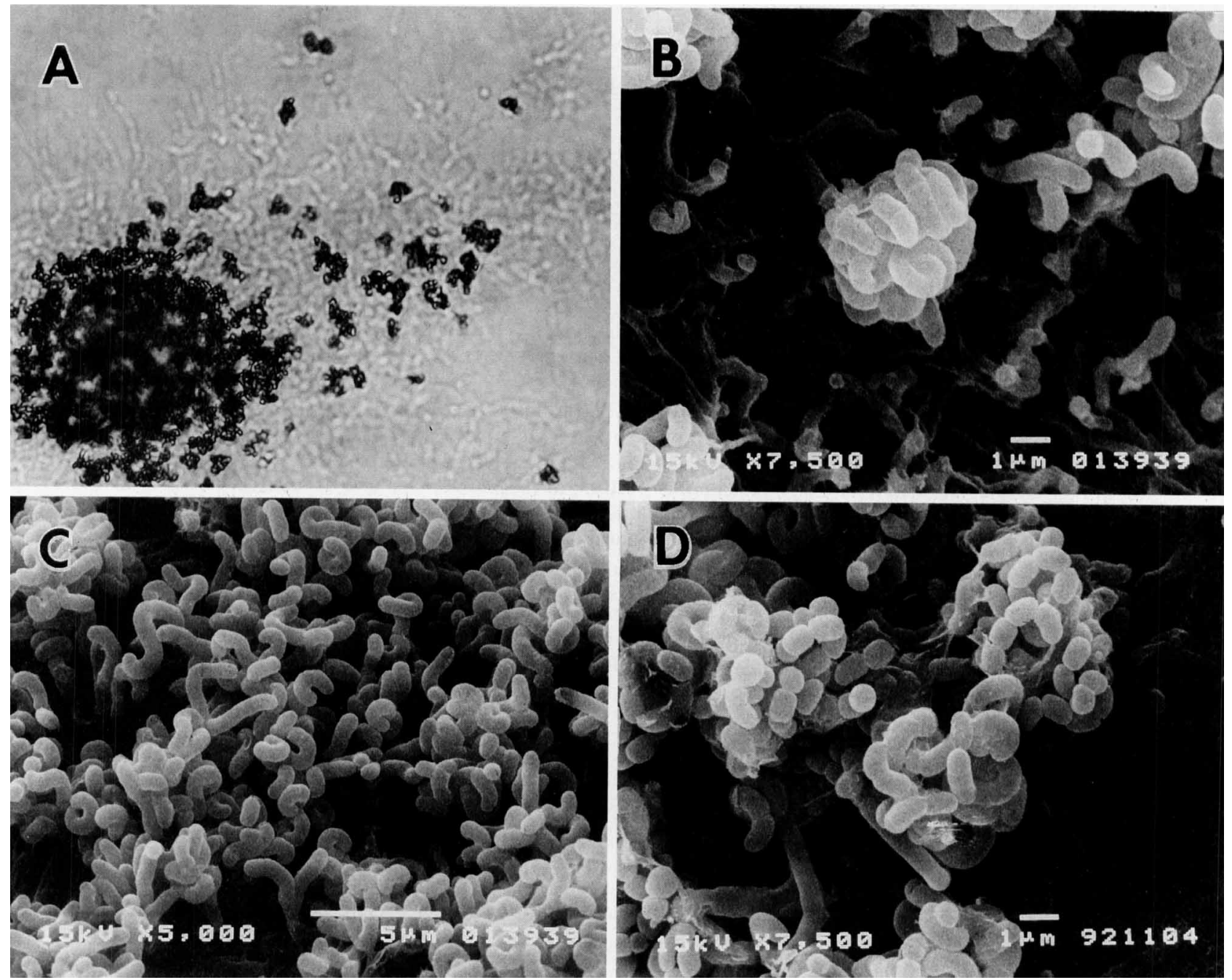

FIG. 1. Light micrograph (A) and scanning electron micrographs (B through D) of Couchioplanes caeruleus subsp. caeruleus IFO $13939^{\mathrm{T}}$ grown on $\mathrm{HV}$ agar for 14 days at $28^{\circ} \mathrm{C}$.

microscope (model JSM-5400; JEOL Ltd.). Samples for scanning electron microscopy were prepared by cutting a block from the agar on which a culture grew, fixing the block in osmium tetroxide vapor at room temperature for $4 \mathrm{~h}$, dehydrating the cells through a graded ethanol series and then in a Hitachi model HCP-2 critical point drying apparatus, and sputter coating the preparation with palladium under a vacuum.

Freeze-dried cells for chemotaxonomic analysis were obtained from cultures grown in yeast extract-glucose broth (containing $10 \mathrm{~g}$ of yeast extract and $10 \mathrm{~g}$ of $\mathrm{D}$-glucose per 1,000 $\mathrm{ml}$ of distilled water; $\mathrm{pH} 7.0$ ) on a rotary shaker at $28^{\circ} \mathrm{C}$.

Peptidoglycan analysis. Cell walls were prepared from ca. $500 \mathrm{mg}$ of dry cells by mechanical disruption with an ultrasonic oscillator and were purified as described by Schleifer and Kandler (22). The amino acid compositions of complete wall hydrolysates were determined by high-performance liquid chromatography (HPLC) with a model LC-6AD apparatus (Shimadzu Co., Ltd., Kyoto, Japan) equipped with a Wakopak WS-PTC column (Wako Pure Chemical Ind., Ltd., Osaka, Japan); the amino acid phenyl thiocarbamoyl derivatives were identified according to the manufacturer's instructions (30).
The amino acid compositions were also examined by developing preparations on cellulose thin-layer chromatography plates (Tokyo Kasei Co., Ltd., Tokyo, Japan), using two-dimensional descending chromatography and the method of Harper and Davis (5). Amino acid configurations were determined by measuring the amino acid contents of the hydrolysates before and after incubation with D- and L-amino acid oxidases (alanine and serine), L-lysine decarboxylase (lysine), and L-glutamic acid decarboxylase (glutamic acid), using the method of Kandler and König (11).

Cell wall sugar analysis. Cell walls were hydrolyzed with $2 \mathrm{~N}$ $\mathrm{HCl}$ at $100^{\circ} \mathrm{C}$ for $2 \mathrm{~h}$, dried in vacuo, and then analyzed by the method of Mikami and Ishida (16) by using a Shimadzu model LC-5A HPLC apparatus equipped with a Shim-pack ISA $07 / \mathrm{S} 2504$ column $(250$ by $4 \mathrm{~mm})$ and a Shimadzu model RE-530 spectrofluorometer.

Glycolyl analysis. The glycolyl test was performed by the method of Uchida and Aida (28).

Analysis of cellular fatty acids. Fatty acids were extracted from $50 \mathrm{mg}$ of dry cells by acid methanolysis and were examined by using a gas-liquid chromatograph (model GC-9A; Shimadzu) equipped with a glass column ( $2 \mathrm{~mm}$ by $5 \mathrm{~m}$ ) 

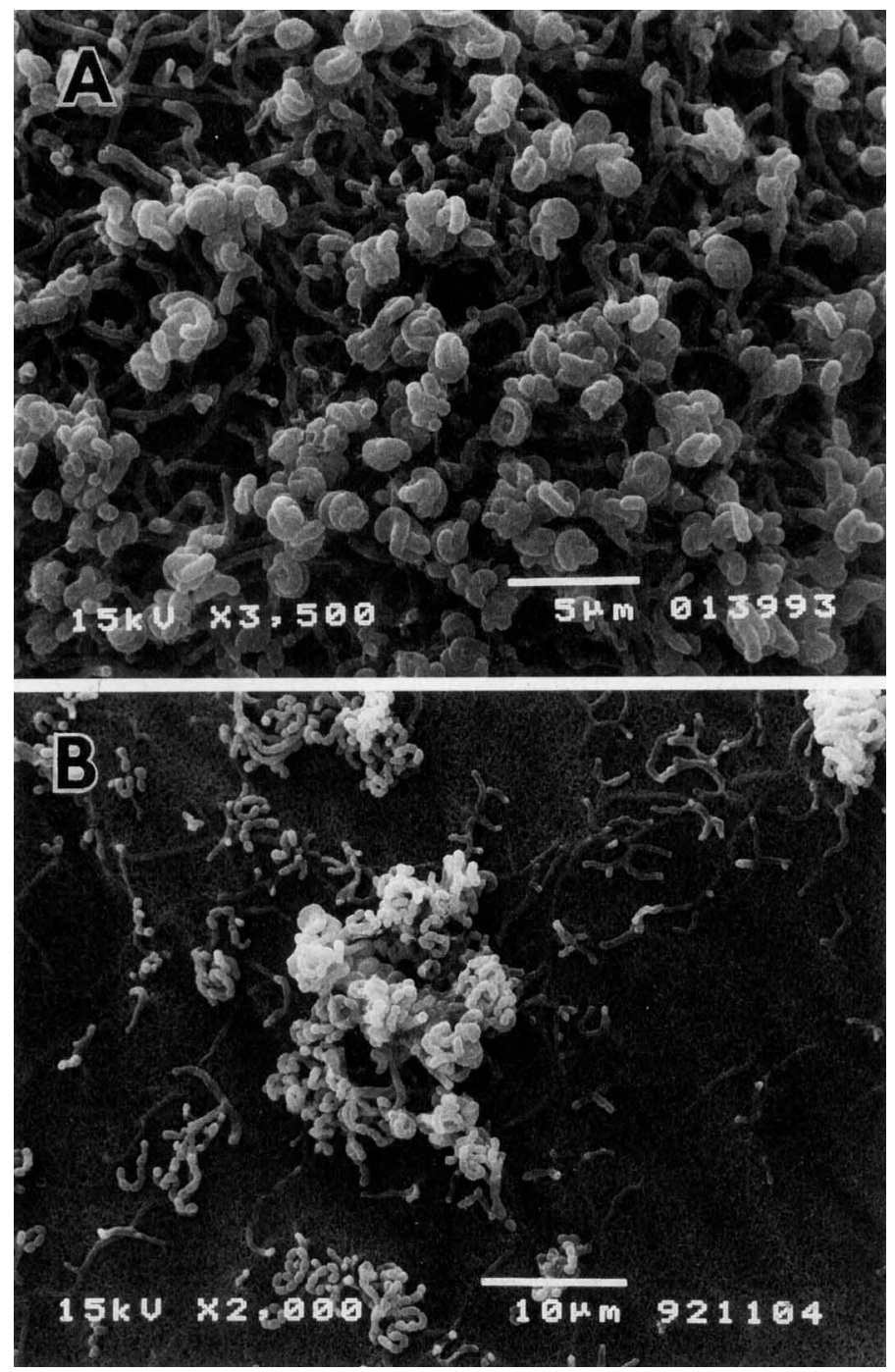

FIG. 2. Scanning electron micrograph of Couchioplanes caeruleus subsp. azureus IFO $13993^{\mathrm{T}}$ grown on HV agar for 14 days at $28^{\circ} \mathrm{C}$.

containing $10 \%$ diethyleneglycol succinate on Chromosorb $\mathrm{W}$ at $180^{\circ} \mathrm{C}(26)$.

Analysis of polar lipids. Free lipids were extracted from 100 mg of dry cells, purified by the method of Minnikin et al. (18), and examined by two-dimensional thin-layer chromatography, using Kiesel gel $60 \mathrm{~F}_{254}$ plates. Lipids were visualized by spraying preparations with $10 \%$ molybdophosphoric acid in ethanol and then heating them at $140^{\circ} \mathrm{C}$ for $10 \mathrm{~min}$. Specific spray reagents for lipid phosphate, $\alpha$-naphthol (sugar), and ninhydrin (amino groups) were also used.

Analysis of mycolic acids. Mycolic acids were analyzed by the method of Minnikin et al. (17).

Analysis of isoprenoid quinones. Menaquinones were extracted from $200 \mathrm{mg}$ of dry cells with chloroform-methanol $(2: 1, \mathrm{vol} / \mathrm{vol})$, purified by thin-layer chromatography in which hexane-diethyl ether $(1: 1, \mathrm{vol} / \mathrm{vol})$ was used as the solvent, extracted with diethyl ether, dried with a stream of nitrogen, and then analyzed by HPLC by using a Shimadzu model LC-5A apparatus equipped with a Zorbax octyldecyl silane column ( 4.6 by $150 \mathrm{~mm}$ ). Methanol-isopropyl ether (7:1) was used as the mobile phase.

DNA base composition. DNA was obtained by the method of
Saito and Miura (20). The guanine-plus-cytosine $(\mathrm{G}+\mathrm{C})$ content of DNA was determined by the method of Mesbah et al. (15) after treatment with P1 nuclease and alkaline phosphatase by using a Shimadzu model LC-6AD HPLC apparatus equipped with a Cosmosil $5 \mathrm{C}_{18}$-AR column $(4.6$ by $150 \mathrm{~mm}$; Nacalai Tesque, Inc., Kyoto, Japan); $0.2 \mathrm{M}$ ammonium phosphate-acetonitrile (40:1) was used as the mobile phase.

DNA-DNA hybridization. DNA-DNA relatedness was measured fluorometrically by the method of Ezaki et al. (3), using biotinylated DNA.

PCR and sequencing of the products. In order to generate sequence templates, a PCR was performed twice. First, 16S rRNA genes were amplified by a PCR by using a standard protocol (19), with some modifications (each $100 \mu \mathrm{l}$ of reaction mixture contained each of the primers at a concentration of 20 $\mathrm{nM}, 50$ to $100 \mathrm{ng}$ of total DNA, and $2.5 \mathrm{U}$ of AmpliTaq DNA polymerase [Cetus Inc.]). The sequences of the primers used for the PCR were identical to the sequence at positions 10 to 25 (5'-AGTTTGATCCTGGCTC-3'; primer 9F) in the Escherichia coli numbering system of Brosius et al. (1), identical to the sequence at positions 343 to 357 (5'-TACGGGAGGCA GCAG-3'; primer $340 \mathrm{~F}$ ), complementary to the sequence at 


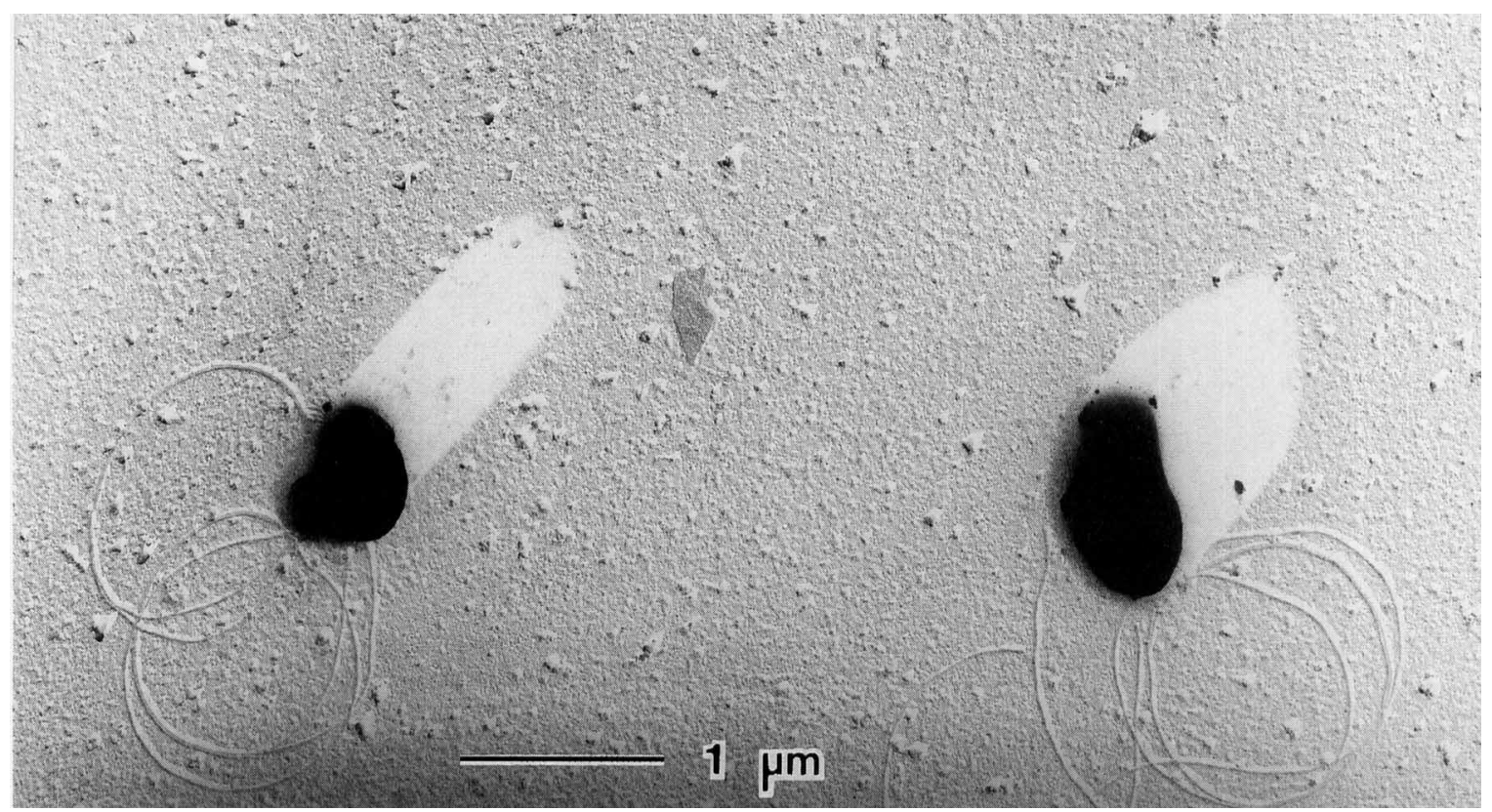

FIG. 3. Flagellation of Couchioplanes caeruleus subsp. caeruleus IFO $13939^{\mathrm{T}}$.

positions 512 to 529 with bases complementary to primer M13 (5'-TGTAAAACGACGGCCAGT-3'; primer M) (5'-[M] GAATTACCGCGGCTGCTG-3'; primer M519R), complementary to the sequence at the positions 905 to 924 with the sequence of primer M (5'-[M]CCGTCAATTCATTTAAGT TT- $3^{\prime}$; primer M907R), and complementary to the sequence at positions 1406 to 1392 with the sequence of primer $M\left(5^{\prime}\right.$ [M]ACGGGCGGTGTGTAC-3'; primer M1392R). Using a primer with bases added to the $5^{\prime}$ end gave products which had the same sequence as the dye-labelled primer. The temperature program $\left(30 \mathrm{~s}\right.$ at $98^{\circ} \mathrm{C}, 30 \mathrm{~s}$ at 50 or $55^{\circ} \mathrm{C}$, and $2 \mathrm{~min}$ at $72^{\circ} \mathrm{C} ; 25$ cycles after 2 min at $98^{\circ} \mathrm{C}$ ) was carried out with a Perkin-Elmer Cetus DNA thermal cycler.

Nucleotide sequences were determined by using a model 373A DNA sequencer and a dye primer cycle sequencing kit (catalog no. 21M13; Applied Biosystems, Foster City, Calif.) according to the manufacturer's directions.

Analysis of nucleotide sequences and nucleotide sequence accession numbers. DNA sequences were aligned by using the ODEN system (10). Evolutionary distances were represented by $K_{\text {nuc }}$ values as described by Kimura (12), and a phylogenetic tree was constructed by the neighbor-joining method (21) from $K_{\text {nuc }}$ values derived from the sequences determined in this study and sequences available from the EMBL and GenBank nucleotide sequence data bases under the following accession numbers: Actinomyces viscosus DSM 43027, M53225; Actinoplanes philippinensis, X72864; Aeromicrobium erythreum NRRL B-3381 ${ }^{\mathrm{T}}$, M37200; Amycolatopsis azurea NRRL $11412^{\mathrm{T}}$, X53199; "Amycolata petrophila" IFAM 78, X55608; Arthrobacter globiformis, M23411; Clavibacter xyli, M60935; Corynebacterium xerosis, M59058; Dactylosporangium aurantiacum, X72779; Frankia sp., M55343; Gordona terrae DSM 43249 ${ }^{\mathrm{T}}$, X53202; Kibdelosporangium aridum, X53191; Kurthia zopfii, M58800; Micrococcus luteus, M38242; Mycobacterium intracellulare ATCC 15985, X52927; Nocardia asteroides ATCC 3306, X57949; Nocardioides simplex ATCC 6946 ${ }^{\mathrm{T}}$, X53213; Nocardioides albus DSM 43109 ${ }^{\mathrm{T}}$, X53211; Propionibacterium freudenreichii DSM 20271 ${ }^{\mathrm{T}}$, X53217; Pseudonocardia ther- mophila ATCC $19285^{\mathrm{T}}$, X53195; Renibacterium salmoninarum ATCC $33209^{\mathrm{T}}$, X51601; Rhodococcus erythropolis DSM 43188, X53203; Saccharomonospora viridis ATCC 15386 ${ }^{\mathbf{T}}$, X54286; Saccharopolyspora erythraea NRRL 2338 ${ }^{\mathrm{T}}$, X53198; Saccharopolyspora hordei, X53197; Saccharopolyspora rectivirgula, X53194; Saccharothrix australiensis, X53192; Streptomyces griseus KCTC 9080, M76388; Streptomyces coelicolor A3, Y00411; Streptomyces setae, M55220; Terrabacter tumescens NCIB 8914 ${ }^{\mathrm{T}}$, X53215; and Tsukamurella paurometabola DSM $20162^{\mathrm{T}}$, X53206. The sequences of $16 \mathrm{~S}$ rRNAs determined for Catenuloplanes japonicus IFO 14176, IFO 14177, and RA 330 and $A$. caeruleus IFO $13939^{\mathrm{T}}$ were deposited in the DNA Data Bank of Japan Data Library under accession numbers D14642, D14643, D14644, and D14645, respectively. The topology of the trees was evaluated by bootstrap analysis of the sequence data by using the Clustal V program (8).

\section{RESULTS AND DISCUSSION}

Morphological observations. Actinoplanes caeruleus IFO $13939^{\mathrm{T}}$, "Actinoplanes azureus" IFO $13993^{\mathrm{T}}$, and isolate RA 335 developed branched aerial mycelia. Spores were formed in chains. Sporangia were not observed. The spore chains and aerial mycelia often aggregated into clusters resembling sporangia, but these clusters were not true sporangia because they were not covered with a sheath (Fig. 1A and B and 2). Morphological observation of a 14-day-old culture grown on $\mathrm{HV}$ agar revealed the presence of an aerial mycelium with short spore chains arranged in irregular spirals, which might have arisen from the substrate mycelium. Several spores per spore chain were observed, and the spores were oval to short rods $(0.5$ to 0.9 by 1.0 to $1.5 \mu \mathrm{m})$ and smooth, as revealed by scanning electron microscopy (Fig. $1 \mathrm{C}$ and $\mathrm{D}$ ).

After incubation at $28^{\circ} \mathrm{C}$ for $1 \mathrm{~h}$ in $0.01 \mathrm{M}$ phosphate buffer (pH 7.0) containing $10 \%$ soil extract, many spores exhibited active motility. The zoospores had polar or nearly polar flagella (Fig. 3).

Growth characteristics. As shown in Table 1, the three 


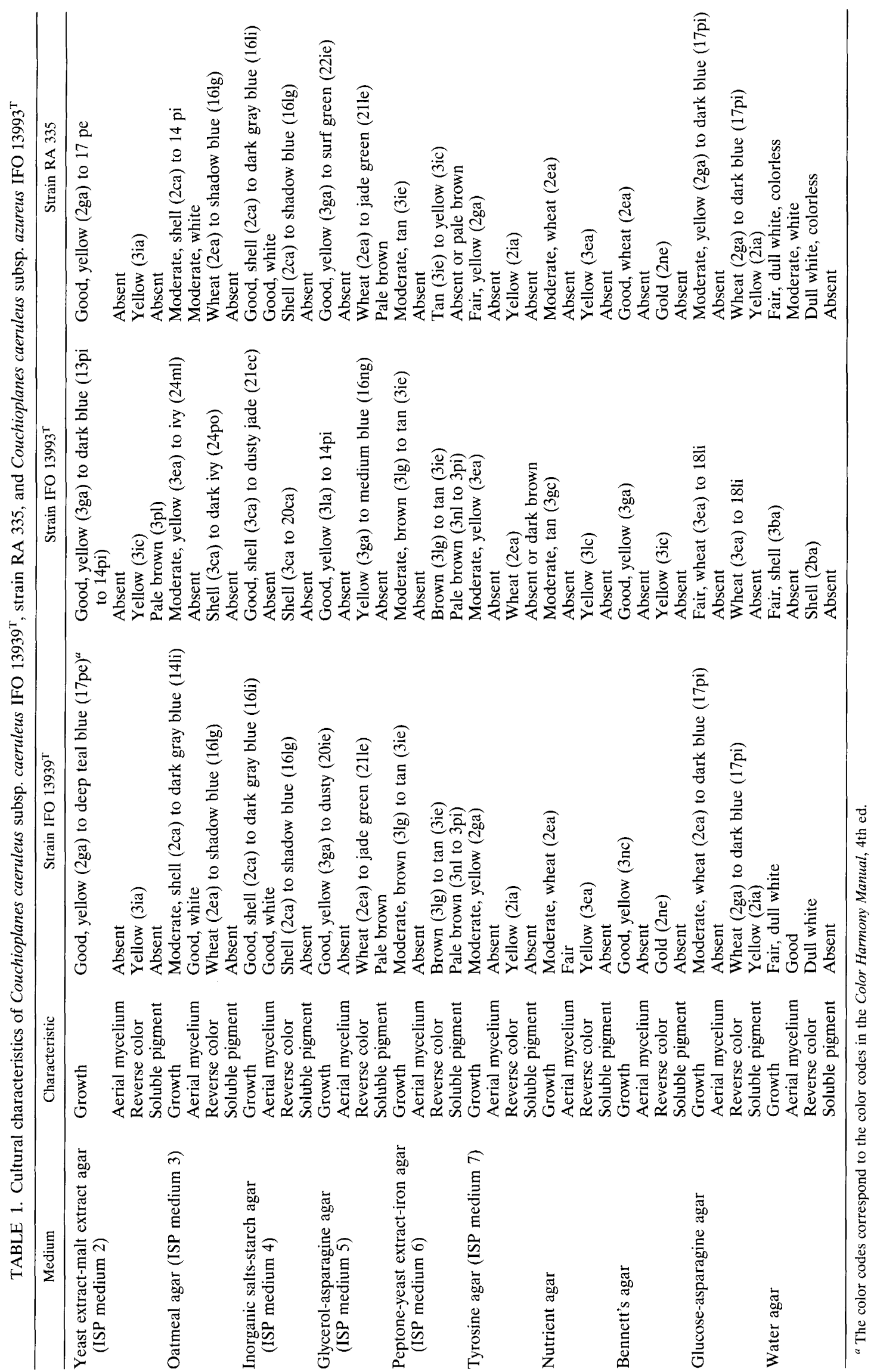


TABLE 2. Phenotypic characteristics of Couchioplanes caeruleus subsp. caeruleus IFO $13939^{\mathrm{T}}$ and RA 335 and Couchioplanes caeruleus subsp. azureus IFO $13993^{\mathrm{T}}$

\begin{tabular}{|c|c|c|}
\hline Characteristic & $\begin{array}{l}\text { Strains IFO } 13939^{\mathrm{T}} \\
\text { and RA } 335\end{array}$ & $\begin{array}{c}\text { Strain IFO } \\
13993^{\mathrm{T}}\end{array}$ \\
\hline \multicolumn{3}{|l|}{ Utilization of: } \\
\hline Glucose & $++^{a}$ & ++ \\
\hline D-Xylose & - & - \\
\hline Inositol & ++ & ++ \\
\hline Sucrose & ++ & ++ \\
\hline Raffinose & - & - \\
\hline Rhamnose & ++ & - \\
\hline D-Mannitol & ++ & \pm \\
\hline D-Fructose & ++ & + \\
\hline D-Arabinose & - & - \\
\hline \multicolumn{3}{|l|}{ Pigmentation in ${ }^{b}$ : } \\
\hline $\begin{array}{l}\text { Tryptone-yeast extract broth } \\
\text { (ISP medium 1) }\end{array}$ & $\mathbf{P}$ & $\mathbf{P}$ \\
\hline $\begin{array}{l}\text { Yeast extract-malt extract agar } \\
\text { (ISP medium 2) }\end{array}$ & A & $\mathbf{P}$ \\
\hline $\begin{array}{l}\text { Glycerol-asparagine agar (ISP } \\
\text { medium 5) }\end{array}$ & $\mathbf{P}$ & A \\
\hline Glucose-asparagine agar & $\mathrm{P}$ & A \\
\hline Gelatin liquefaction & $\mathbf{P}$ & $\mathbf{P}$ \\
\hline Peptonization of milk & A & A \\
\hline Starch hydrolysis & $\mathbf{P}$ & $\mathbf{P}$ \\
\hline Calcium malate hydrolysis & A & A \\
\hline Reduction of nitrate & $\mathrm{P}$ & $\mathbf{P}$ \\
\hline $\mathrm{H}_{2} \mathrm{~S}$ production & $\mathbf{P}$ & $\mathbf{P}$ \\
\hline Growth in $1 \% \mathrm{NaCl}$ & $\mathrm{P}$ & $\mathbf{P}$ \\
\hline Growth in $2 \% \mathrm{NaCl}$ & A & $\mathbf{P}$ \\
\hline Growth in $3 \% \mathrm{NaCl}$ & A & A \\
\hline
\end{tabular}

a Abbreviations: ++ , good; + , moderate; \pm , poor; - , none; $\mathrm{P}$, present; $\mathrm{A}$, absent.

${ }^{b}$ For pigment colors on yeast extract-malt extract agar, glycerol-asparagine agar, and glucose-asparagine agar, see Table 1. In tryptone-yeast extract broth the pigment was pale brown for all organisms.

strains had nearly the same cultural characteristics. Young colonies were yellow to orange, and later the colony color changed to dark green to dark blue. All of the strains grew well on yeast extract-malt extract agar (ISP medium 2), inorganic salts-starch agar (ISP medium 4), glycerol-asparagine agar (ISP medium 5), and Bennett's agar and produced a pale brown soluble pigment on peptone-yeast extract-iron agar (ISP medium 6). However, Actinoplanes caeruleus IFO $13939^{\mathrm{T}}$ and isolate RA 335 differed from "Actinoplanes azureus" IFO $13993^{\mathrm{T}}$ in that the former two strains developed aerial mycelia on oatmeal agar (ISP medium 3) and inorganic salts-starch agar (ISP medium 4), produced a soluble pigment on glycerolasparagine agar (ISP medium 5) and glucose-asparagine agar, and did not produce a soluble pigment on yeast extract-malt extract agar (ISP medium 2).
TABLE 4. Phospholipid type and menaquinone compositions of Couchioplanes caeruleus subsp. caeruleus IFO $13939^{\mathrm{T}}$ and RA 335 and Couchioplanes caeruleus subsp. azureus IFO $13993^{\mathrm{T}}$

\begin{tabular}{|c|c|c|c|c|c|}
\hline \multirow{2}{*}{ Strain } & \multirow{2}{*}{$\begin{array}{l}\text { Phospholipid } \\
\text { type }^{a}\end{array}$} & \multicolumn{4}{|c|}{ Menaquinone composition } \\
\hline & & MK-9( $\left.\mathrm{H}_{2}\right)$ & MK-9(H $\left.\mathrm{H}_{4}\right)$ & MK- $9\left(\mathbf{H}_{6}\right)$ & MK-9 $\left(\mathrm{H}_{8}\right)$ \\
\hline IFO $13939^{\mathrm{T}}$ & PII & $t^{b}$ & +++ & + & \\
\hline RA 335 & PII & & +++ & $+t$ & + \\
\hline IFO $13993^{\mathrm{T}}$ & PII & + & +++ & ++ & + \\
\hline
\end{tabular}

${ }^{a}$ Phosphatidylglycerol and phosphatidylethanolamine were detected, but phosphatidylcholine was not detected.

${ }^{b}+++,>50 \% ;++,>10 \% ;+, \leq 10 \%$.

Physiological and biochemical characteristics. Biochemical properties of the three strains are shown in Table 2 . All of the strains were positive for gelatin liquefaction, hydrolysis of starch, and production of $\mathrm{H}_{2} \mathrm{~S}$ and were negative for decomposition of calcium malate and coagulation and clearing of milk. Actinoplanes caeruleus IFO $13939^{\mathrm{T}}$ and isolate RA 335 differed from "Actinoplanes azureus" IFO $13993^{\mathrm{T}}$ in that the former two strains utilized rhamnose and mannitol.

Chemotaxonomic characteristics. The whole-cell sugar patterns, cell wall amino acid compositions, phospholipid types, menaquinone compositions, and cellular fatty acid compositions of the organisms are shown in Tables 3 through 5 . The cell walls contained L-lysine, D- plus L-serine, glycine, Dglutamate, and L-alanine (molar ratio, ca. 1:1:1:1:1), indicating that the wall chemotype of these strains is type VI according to the classification of Lechevalier and Lechevalier (14) and the peptidoglycan type is type A3 $\alpha$ according to the classification of Schleifer and Kandler (22). Strain IFO $13939^{\mathrm{T}}$ contained xylose, glucose, and mannose as the major cell wall sugars in addition to small amounts of arabinose and galactose. Strains IFO $13993^{\mathbf{T}}$ and RA 335 contained xylose, glucose, arabinose, galactose, and mannose as the major cell wall sugars. The major menaquinone was MK-9 $\left(\mathrm{H}_{4}\right)$; small amounts of MK$9\left(\mathrm{H}_{6}\right)$, MK-9 $\left(\mathrm{H}_{8}\right)$, and MK-9 $\left(\mathrm{H}_{2}\right)$ were also present (Table 4). All strains contained iso- $\mathrm{C}_{16: 0}$ and anteiso- $\mathrm{C}_{17: 0}$ as the major cellular fatty acids (Table 5). Mycolic acids were absent. The diagnostic phospholipids were phosphatidylglycerol and phosphatidylethanolamine, but phosphatidylcholine was not detected (phospholipid type II of Hasegawa et al. [6]). The G+C contents of the DNAs were 69.9 to 72.1 mol\% (Table 6).

DNA-DNA hybridization. As shown in Table 6, the results of DNA-DNA hybridization studies indicated that the three strains could be divided into two DNA homology groups. The first group contained two strains, Actinoplanes caeruleus IFO $13939^{\mathbf{T}}$ and RA 335, and the other group was a single-member group containing "Actinoplanes azureus" IFO 13993". The levels of relatedness between members of the two groups ranged from 52 to $62 \%$.

TABLE 3. Cell wall amino acid and whole-cell sugar compositions of Couchioplanes caeruleus subsp. caeruleus IFO $13939^{\mathrm{T}}$ and RA 335 and Couchioplanes caeruleus subsp. azureus IFO $13993^{\mathrm{Ta}}$

\begin{tabular}{|c|c|c|c|c|c|c|c|c|c|c|c|c|}
\hline \multirow{2}{*}{ Strain } & \multicolumn{5}{|c|}{$\begin{array}{c}\text { Amino acid composition } \\
\text { of peptidoglycan (molar ratio) }\end{array}$} & \multicolumn{7}{|c|}{ Sugar composition of whole cells } \\
\hline & Glu & Ser & Gly & Ala & Lys & Ara & Xyl & Gal & Glc & Man & Mad & Rib \\
\hline IFO $13939^{\mathrm{T}}$ & 0.66 & 1.09 & 1.07 & 0.62 & 1.00 & $\operatorname{tr}$ & + & $\operatorname{tr}$ & + & + & - & $\operatorname{tr}$ \\
\hline RA 335 & 1.00 & 1.25 & 1.10 & 0.80 & 1.00 & + & + & + & + & + & - & tr \\
\hline IFO $13993^{T}$ & 0.65 & 1.21 & 1.15 & 0.72 & 1.00 & + & + & + & + & + & - & tr \\
\hline
\end{tabular}

${ }^{a}$ Abbreviations: Glu, glutamic acid; Ser, serine; Gly, glycine; Ala, alanine; Lys, lysine; Ara, arabinose; Gal, galactose; Glc, glucose; Man, mannose; Mad, madurose; Rib, ribose; Xyl, xylose. +, present; - , absent; tr, trace amount present.

${ }^{b}$ Calculated by defining the amount of lysine as 1.0 . 
TABLE 5. Cellular fatty acid compositions of Couchioplanes caeruleus subsp. caeruleus IFO $13939^{\mathrm{T}}$ and RA 335 and Couchioplanes caeruleus subsp. azureus IFO $13993^{\text {T }}$

\begin{tabular}{|c|c|c|c|c|c|c|c|c|c|c|c|c|c|}
\hline \multirow{3}{*}{ Strain } & \multicolumn{13}{|c|}{ Fatty acid composition $(\%)$} \\
\hline & \multicolumn{2}{|c|}{ anteiso-branched fatty acids } & \multicolumn{4}{|c|}{ iso-branched fatty acids } & \multicolumn{3}{|c|}{ Saturated fatty acids } & \multicolumn{3}{|c|}{$\begin{array}{l}\text { Unsaturated fatty } \\
\text { acids }\end{array}$} & \multirow{2}{*}{$\begin{array}{c}\text { 10-methyl } \\
\mathrm{C}_{17: 0}\end{array}$} \\
\hline & anteiso- $C_{15: 0}$ & anteiso- $\mathrm{C}_{17: 0}$ & iso- $\mathrm{C}_{14: 0}$ & iso- $\mathrm{C}_{15: 0}$ & iso- $\mathrm{C}_{16: 0}$ & iso- $C_{18: 0}$ & $C_{16: 0}$ & $\mathrm{C}_{17: 0}$ & $\mathrm{C}_{18 ; 0}$ & $\mathrm{C}_{16: 1}$ & $\mathrm{C}_{17: 1}$ & $\mathrm{C}_{18: 1}$ & \\
\hline IFO $13939^{\mathrm{T}}$ & 16 & 14 & & & 47 & 1 & 10 & 2 & 1 & 2 & 1 & 3 & 1 \\
\hline RA 335 & & 16 & 1 & 12 & 45 & 2 & 7 & 4 & 2 & 1 & 2 & 3 & 2 \\
\hline IFO $13993^{\mathrm{T}}$ & 19 & 20 & 1 & & 22 & & 8 & 2 & 8 & 14 & 1 & 14 & 1 \\
\hline
\end{tabular}

Phylogenetic analysis. The percentages of similarity obtained after pairwise alignment of the sequences from Actinoplanes caeruleus IFO $13939^{\mathrm{T}}$ and representative strains of the genera Actinoplanes, Dactylosporangium, and Catenuloplanes and other actinomycete genera are shown in Table 7 , and a phylogenetic tree derived from the sequences is shown in Fig. 4. Catenuloplanes japonicus IFO $14176^{\mathrm{T}}$, IFO 14177 , and RA 330 were phylogenetically coherent. Actinoplanes caeruleus IFO $13939^{\mathrm{T}}$ could be separated from its taxonomic neighbors, members of the genera Actinoplanes, Dactylosporangium, and Catenuloplanes, and other actinomycete taxa by phylogenetic analysis (Fig. 4).

Although Actinoplanes caeruleus differs from other species of the genus Actinoplanes by forming a deep blue vegetative mycelial pigment, by the absence of diaminopimelic acid in its cell wall, by its ability to hydrolyze adenine and hypoxanthine, by its resistance to lysozyme, and by its inability to utilize L-arabinose, D-xylose, and succinate as sole carbon sources, Horan and Brodsky (9) included this organism in the genus Actinoplanes for the following reasons: it formed irregular to globose sporangia which upon wetting released spherical to oval, partially flagellated, motile spores and contained arabinose and xylose as diagnostic whole-cell sugars. However, Stackebrandt and Kroppenstedt (24) reported that this organism should not be included in this genus because of its peptidoglycan type; the results of numerical taxonomy studies of the genus Actinoplanes performed by Goodfellow et al. (4) support this conclusion. Thus, the taxonomic status of this organism has remained uncertain.

In this study, we observed aerial mycelia and motile arthrospores in Actinoplanes caeruleus, "Actinoplanes azureus," and RA 335 preparations, but no sporangia were observed. The aerial mycelia and arthrospores were intertwined and often developed sporangium-like structures, and during observation with a light microscope these structures often looked like sporangia. Horan and Brodsky (9) used a phase-contrast microscope when they observed "sporangia," but our observations with a scanning electron microscope indicated that these

TABLE 6. $\mathrm{G}+\mathrm{C}$ contents and levels of DNA relatedness among Couchioplanes caeruleus subsp. caeruleus IFO $13939^{\mathrm{T}}$ and RA 335, Couchioplanes caeruleus subsp. azureus IFO $13993^{\mathrm{T}}$, and Catenuloplanes japonicus IFO $14176^{\mathrm{T}}$

\begin{tabular}{lccccc}
\hline \multirow{2}{*}{ Strain } & \multirow{2}{*}{$\begin{array}{c}\mathrm{G}+\mathrm{C} \\
\text { content } \\
(\mathrm{mol})\end{array}$} & \multicolumn{4}{c}{ \% of DNA complementary to labelled } \\
\cline { 3 - 6 } & & IFO 13939 & RA 335 & IFO 13993 & IFO 14176 \\
\hline IFO 13939 & 69.9 & 100 & 101 & 53 & 8 \\
RA 335 & 70.5 & 103 & 100 & 62 & 7 \\
IFO 13993 & 72.1 & 52 & 57 & 100 & 10 \\
IFO 14176 & 71.0 & 2 & 3 & 2 & 100 \\
\hline
\end{tabular}

structures are not sporangia but are intertwined aerial mycelia and arthrospores. Strains IFO $13939^{\mathrm{T}}$, IFO $13993^{\mathrm{T}}$, and RA 335 differ from strains belonging to the genera Actinoplanes, Dactylosporangium, Micromonospora, and Pilimelia of the family Micromonosporaceae (4) in that they contain L-lysine instead of meso-diaminopimelic acid in their cell walls and produce spores within the mycelia arranged in chains instead of enclosed in sporangial walls (Table 8). These strains resemble strains belonging to the genus Catenuloplanes (31) in that they have motile arthrospores and the same cell wall peptidoglycan type (wall chemotype VI and murein type $A 3 \alpha$ ) but differ in their menaquinone system [MK-9 $\left.\left(\mathrm{H}_{4}\right)\right]$, phospholipid type (type II), and cellular fatty acids (iso- $\mathrm{C}_{16: 0}$ and anteiso$\mathrm{C}_{17: 0}$ ) (Tables 5 and 8). Whereas the arthrospores of strains IFO $13939^{\mathrm{T}}$, IFO $13993^{\mathrm{T}}$, and RA 335 are oval to short rods with polar flagella, Catenuloplanes arthrospores are rods with peritrichous flagella.

Thus, on the basis of morphological, biochemical, chemical, and phylogenetical criteria, Actinoplanes caeruleus, "Actinoplanes azureus," and isolate RA 335 can be distinguished readily from the previously described motile actinomycetes and warrant a new taxon. No assimilation of rhamnose, production of a soluble pigment on yeast extract-malt extract agar (ISP medium 2), no production of a soluble pigment on glycerolasparagine agar (ISP medium 5) and glucose-asparagine agar, and DNA-DNA similarity values suggest that "Actinoplanes azureus" should be classified as a subspecies of Actinoplanes caeruleus. The subspecies can be differentiated on the basis of characteristics summarized in Table 9.

Therefore, we propose that strains IFO $13939^{\mathrm{T}}$ and RA 335 should be placed in a new genus, Couchioplanes, with Couchioplanes caeruleus comb. nov. (type strain, IFO 13939) as the type species and that strain IFO 13993 should be placed in a new subspecies, Couchioplanes caeruleus subsp. azureus (type strain, IFO 13993).

Tille et al. (27) described strain IMET 9075, which produced a blue substrate mycelium, did not utilize xylose, and contained lysine instead of meso-diaminopimelic acid in its cell wall. Our results suggest that strain IMET 9075 may also belong to the new genus Couchioplanes.

Although there are many differences between the genus Couchioplanes and other genera belonging to the family $\mathrm{Mi}$ cromonosporaceae with regard to morphological and chemotaxonomic characteristics, the genus Couchioplanes, together with the recently described genus Catenuloplanes (31), should be placed in the family Micromonosporaceae Krassil'nikov 1938 emend. Goodfellow et al. 1990 (4) on the basis of the results of the comparative analysis of $16 \mathrm{~S}$ rRNA sequences described in this paper and the comparative $16 \mathrm{~S}$ rRNA cataloging results reported by Stackebrandt et al. (25).

Description of Couchioplanes gen. nov. Couchioplanes (Couch'i.o.pla.nes. N.L. adj. Couchio, referring to J. N. Couch [1896 
TABLE 7. Nucleotide substitution rates ( $K_{\text {nuc }}$ values) for the $16 \mathrm{~S}$ rRNA sequences of members of the genera Couchioplanes and Catenuloplanes and related actinomycete genera

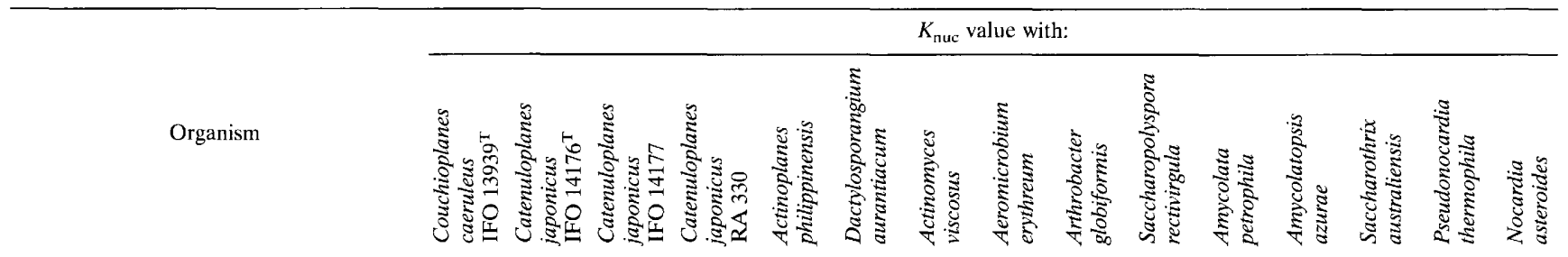

Couchioplanes caeruleus IFO $13939^{\mathrm{T}}$ Catenuloplanes japonicus IFO $14176^{\mathrm{T}}$ Catenuloplanes japonicus IFO 14177 Catenuloplanes japonicus RA 330 Actinoplanes philippinensis Dactylosporangium aurantiacum Actinomyces viscosus Aeromicrobium erythreum Arthrobacter globiformis Saccharopolyspora rectivirgula Amycolata petrophila Amycolatopsis azurae Saccharothrix australiensis Pseudonocardia thermophila Nocardia asteroides

Streptomyces (Kitasatosporia) setae Kibdelosporangium aridum

Tsukamurella paurometabola Saccharomonospora viridis Saccharopolyspora hordei Saccharopolyspora erythraea Streptomyces griseus Nocardioides albus Nocardioides simplex Micrococcus luteus Gordona terrae

Corynebacterium xerosis Rhodococcus erythropolis Clavibacter xyli Renibacterium salmoninarum Propionibacterium freudenreichii Terrabacter tumescens Mycobacterium intracellulare Streptomyces coelicolor Nocardioides fastidiosa Nocardioides luteus

\begin{tabular}{|c|c|c|c|c|c|c|c|c|c|c|c|c|c|c|}
\hline 0.020 & & & & & & & & & & & & & & \\
\hline 0.020 & 0.008 & & & & & & & & & & & & & \\
\hline 0.023 & 0.010 & 0.010 & & & & & & & & & & & & \\
\hline 0.031 & 0.035 & 0.035 & 0.037 & & & & & & & & & & & \\
\hline 0.041 & 0.038 & 0.037 & 0.039 & 0.039 & & & & & & & & & & \\
\hline 0.097 & 0.089 & 0.089 & 0.092 & 0.096 & 0.087 & & & & & & & & & \\
\hline 0.071 & 0.070 & 0.073 & 0.074 & 0.067 & 0.072 & 0.110 & & & & & & & & \\
\hline 0.067 & 0.077 & 0.077 & 0.078 & 0.073 & 0.077 & 0.085 & 0.065 & & & & & & & \\
\hline 0.074 & 0.075 & 0.075 & 0.079 & 0.069 & 0.070 & 0.107 & 0.088 & 0.099 & & & & & & \\
\hline 0.078 & 0.079 & 0.082 & 0.081 & 0.074 & 0.081 & 0.095 & 0.083 & 0.092 & 0.084 & & & & & \\
\hline 0.059 & 0.063 & 0.060 & 0.064 & 0.059 & 0.058 & 0.100 & 0.079 & 0.084 & 0.063 & 0.084 & & & & \\
\hline 0.055 & 0.056 & 0.059 & 0.060 & 0.054 & 0.060 & 0.100 & 0.072 & 0.090 & 0.066 & 0.071 & 0.054 & & & \\
\hline 0.065 & 0.063 & 0.063 & 0.067 & 0.062 & 0.054 & 0.095 & 0.079 & 0.092 & 0.048 & 0.067 & 0.060 & 0.055 & & \\
\hline 0.050 & 0.054 & 0.054 & 0.055 & 0.044 & 0.055 & 0.088 & 0.060 & 0.061 & 0.077 & 0.070 & 0.060 & 0.055 & 0.064 & \\
\hline 0.070 & 0.071 & 0.071 & 0.073 & 0.067 & 0.073 & 0.097 & 0.064 & 0.068 & 0.098 & 0.093 & 0.077 & 0.075 & 0.085 & 0.061 \\
\hline 0.053 & 0.051 & 0.054 & 0.058 & 0.045 & 0.060 & 0.097 & 0.064 & 0.074 & 0.067 & 0.067 & 0.055 & 0.051 & 0.058 & 0.051 \\
\hline 0.060 & 0.067 & 0.064 & 0.068 & 0.066 & 0.073 & 0.104 & 0.073 & 0.065 & 0.089 & 0.070 & 0.060 & 0.064 & 0.075 & 0.038 \\
\hline 0.073 & 0.074 & 0.070 & 0.078 & 0.071 & 0.075 & 0.113 & 0.090 & 0.094 & 0.074 & 0.088 & 0.068 & 0.068 & 0.068 & 0.070 \\
\hline 0.072 & 0.071 & 0.071 & 0.075 & 0.063 & 0.073 & 0.107 & 0.083 & 0.090 & 0.051 & 0.087 & 0.056 & 0.071 & 0.062 & 0.074 \\
\hline 0.082 & 0.079 & 0.081 & 0.086 & 0.077 & 0.081 & 0.119 & 0.100 & 0.109 & 0.070 & 0.089 & 0.063 & 0.081 & 0.078 & 0.085 \\
\hline 0.073 & 0.069 & 0.071 & 0.073 & 0.071 & 0.071 & 0.099 & 0.070 & 0.072 & 0.096 & 0.098 & 0.078 & 0.079 & 0.086 & 0.065 \\
\hline 0.077 & 0.079 & 0.079 & 0.081 & 0.075 & 0.082 & 0.114 & 0.051 & 0.075 & 0.093 & 0.096 & 0.092 & 0.085 & 0.095 & 0.073 \\
\hline 0.075 & 0.077 & 0.074 & 0.078 & 0.077 & 0.081 & 0.107 & 0.051 & 0.069 & 0.088 & 0.084 & 0.079 & 0.079 & 0.082 & 0.068 \\
\hline 0.067 & 0.077 & 0.076 & 0.078 & 0.073 & 0.078 & 0.085 & 0.070 & 0.017 & 0.097 & 0.091 & 0.088 & 0.084 & 0.089 & 0.061 \\
\hline 0.061 & 0.063 & 0.063 & 0.067 & 0.063 & 0.063 & 0.093 & 0.063 & 0.062 & 0.073 & 0.074 & 0.060 & 0.060 & 0.060 & 0.028 \\
\hline 0.077 & 0.084 & 0.082 & 0.081 & 0.077 & 0.081 & 0.099 & 0.086 & 0.076 & 0.086 & 0.081 & 0.086 & 0.079 & 0.084 & 0.059 \\
\hline 0.063 & 0.064 & 0.062 & 0.066 & 0.056 & 0.056 & 0.099 & 0.064 & 0.074 & 0.067 & 0.074 & 0.056 & 0.060 & 0.052 & 0.030 \\
\hline 0.078 & 0.084 & 0.082 & 0.085 & 0.080 & 0.088 & 0.106 & 0.075 & 0.053 & 0.103 & 0.098 & 0.088 & 0.085 & 0.098 & 0.078 \\
\hline 0.087 & 0.096 & 0.098 & 0.099 & 0.093 & 0.098 & 0.108 & 0.088 & 0.030 & 0.112 & 0.112 & 0.105 & 0.103 & 0.105 & 0.081 \\
\hline 0.111 & 0.112 & 0.111 & 0.117 & 0.115 & 0.113 & 0.113 & 0.089 & 0.099 & 0.121 & 0.103 & 0.115 & 0.113 & 0.116 & 0.091 \\
\hline 0.070 & 0.078 & 0.078 & 0.079 & 0.072 & 0.080 & 0.106 & 0.078 & 0.050 & 0.111 & 0.093 & 0.087 & 0.088 & 0.096 & 0.066 \\
\hline 0.070 & 0.073 & 0.075 & 0.073 & 0.074 & 0.070 & 0.096 & 0.070 & 0.075 & 0.075 & 0.070 & 0.073 & 0.066 & 0.068 & 0.043 \\
\hline 0.070 & 0.071 & 0.071 & 0.073 & 0.067 & 0.070 & 0.105 & 0.077 & 0.069 & 0.093 & 0.095 & 0.077 & 0.079 & 0.086 & 0.063 \\
\hline 0.088 & 0.085 & 0.084 & 0.089 & 0.083 & 0.083 & 0.118 & 0.026 & 0.078 & 0.093 & 0.097 & 0.090 & 0.086 & 0.090 & 0.079 \\
\hline 0.075 & 0.079 & 0.079 & 0.081 & 0.074 & 0.081 & 0.116 & 0.050 & 0.074 & 0.095 & 0.095 & 0.090 & 0.083 & 0.093 & 0.071 \\
\hline
\end{tabular}

to 1986], a mycologist who contributed to the taxonomy of the family Actinoplanaceae; Gr. n. planes, a wanderer; M.L.masc.n. Couchioplanes, Couch wanderer) strains are gram-positive, non-acid-fast, aerobic organisms with branching hyphae. Nonfragmenting, yellowish orange to blue mycelia are present. Spores are formed in chains and are motile. The spore chains and aerial mycelia often aggregate into clusters resembling sporangia, but true sporangia are not observed. In 14-day-old cultures grown on oatmeal agar aerial mycelia with short spore chains arranged in spirals that have one to five turns and are hooked or rarely flexuous are present. Several spores are present per spore chain, and the spores are oval to short rods (diameter, 1.3 to $2.0 \mu \mathrm{m}$ ) and exhibit motility when they are suspended in sterile distilled water.

Strictly aerobic. Good growth occurs at temperatures between 22 and $28^{\circ} \mathrm{C}$. The organisms grow well on yeast extractmalt extract agar, inorganic salts-starch agar, glycerol-asparagine agar, and Bennett's agar. In general, the vegetative mycelia of the strains are pale orange to blue, and the aerial mycelia are white to gray.
Cell walls contain D-glutamate, D- and L-serine, glycine, L-alanine, and L-lysine (molar ratio, ca. 1:1:1:1:1). The wall chemotype is type VI according to the classification of Lechevalier and Lechevalier (14), and the peptidoglycan type is type A (most probably type A $3 \alpha$ ) according to the classification of Schleifer and Kandler (22). Xylose, arabinose, and galactose are the characteristic cell wall sugars; iso-pentadecanoic acid (iso- $\mathrm{C}_{16: 0}$ ) and anteiso-heptadecanoic acid (anteiso- $\mathrm{C}_{17: 0}$ ) are the major cellular fatty acids. The $\mathrm{G}+\mathrm{C}$ contents of DNAs range from 69 to $73 \mathrm{~mol} \%$; the $\mathrm{G}+\mathrm{C}$ contents of the type species range from 69.9 to $70.5 \mathrm{~mol} \%$. The major menaquinone is MK- $9\left(\mathrm{H}_{4}\right)$; in addition, small amounts of MK- $9\left(\mathrm{H}_{6}\right)$, MK- $9\left(\mathrm{H}_{8}\right)$, and MK-9 $\left(\mathrm{H}_{2}\right)$ are also present. Phosphatidylglycerol and phosphatidylethanolamine are the diagnostic phospholipids, but phosphatidylcholine is absent (type PII). Habitat: soil.

The type species is Couchioplanes caeruleus.

Description of Couchioplanes caeruleus (Horan and Brodsky 1986) comb. nov. Couchioplanes caeruleus (cae. ru'le. us. L. masc. adj. caeruleus, dark blue, referring to the blue vegetative 
TABLE 7-Continued

\begin{tabular}{|c|c|c|c|c|c|c|c|c|c|c|c|c|c|c|c|c|c|c|c|}
\hline \multicolumn{20}{|c|}{$K_{\text {nuc }}$ value with: } \\
\hline 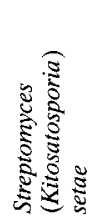 & 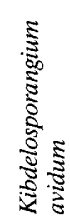 & 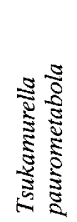 & 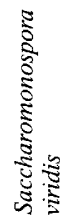 & 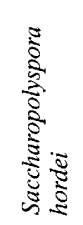 & 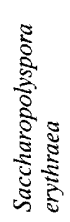 & 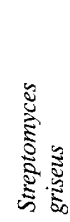 & 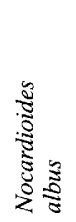 & 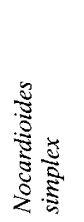 & 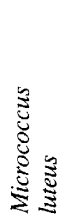 & 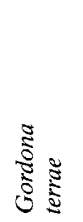 & 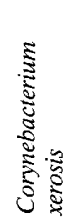 & 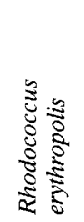 & 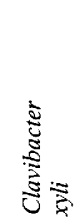 & 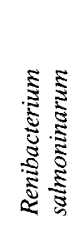 & 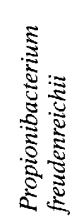 & 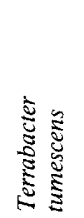 & 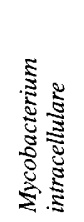 & 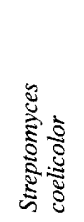 & 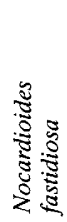 \\
\hline
\end{tabular}

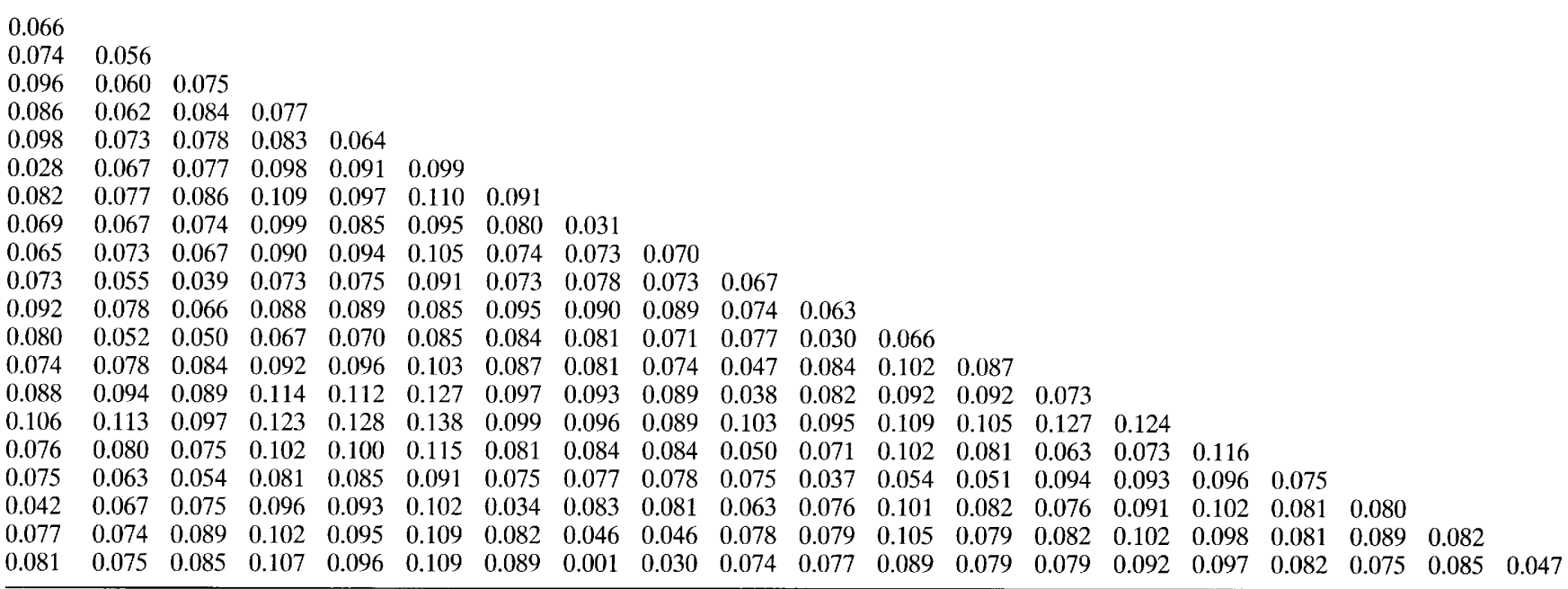

mycelial pigment). The morphological, chemotaxonomic, and general characteristics of this species are the same as those given above for the genus. A yellow to pale brownish soluble pigment is produced on peptone-yeast extract-iron agar. Hydrogen sulfide is produced. Reduces nitrate to nitrite. Gelatin liquefaction is positive. Hydrolyzes starch. Does not decompose calcium malate. Does not coagulate milk. Fructose, glucose, inositol, and sucrose are utilized as carbon sources, but arabinose, raffinose, and xylose are not. The $\mathrm{G}+\mathrm{C}$ contents of the DNAs range from 69 to $73 \mathrm{~mol} \%$.

The type strain is IFO 13939 (= ATCC 33937).

Actinoplanes caeruleus (9) is the basonym of this species.

Description of Couchioplanes caeruleus subsp. caeruleus subsp. nov. The morphological, chemotaxonomic, and general characteristics of Couchioplanes caeruleus subsp. caeruleus are the same as those given above for the species. In addition, a yellow to pale brownish soluble pigment is produced on glycerol-asparagine agar and glucose-asparagine agar, but this pigment is not produced on yeast extract-malt extract agar.
Rhamnose and mannitol are utilized as carbon sources. No growth occurs in the presence of $2 \% \mathrm{NaCl}$. The $\mathrm{G}+\mathrm{C}$ content of the DNA of the type strain is $70 \mathrm{~mol} \%$. Habitat: soil.

The type strain is IFO 13939.

Description of Couchioplanes caeruleus subsp. azureus subsp. nov. Couchioplanes caeruleus subsp. azureus (a.zur'e. us. M. L. masc. adj. azureus, azure blue, referring to the blue vegetative mycelial pigment). The morphological, chemotaxonomic, and general characteristics of this subspecies are the same as those given above for the species. In addition, a yellow to pale brownish soluble pigment is produced on yeast extract-malt extract agar, but this pigment is not produced glycerolasparagine agar and glucose-asparagine agar. Growth occurs in the presence of $2 \% \mathrm{NaCl}$. Rhamnose is not utilized as a carbon source, and mannitol is weakly utilized. The $\mathrm{G}+\mathrm{C}$ content of the DNA of the type strain is $72 \mathrm{~mol} \%$. Habitat: soil.

The type strain is IFO 13993 (= ATCC 31157).

"Actinoplanes azureus" (2) is the basonym of this subspecies. 


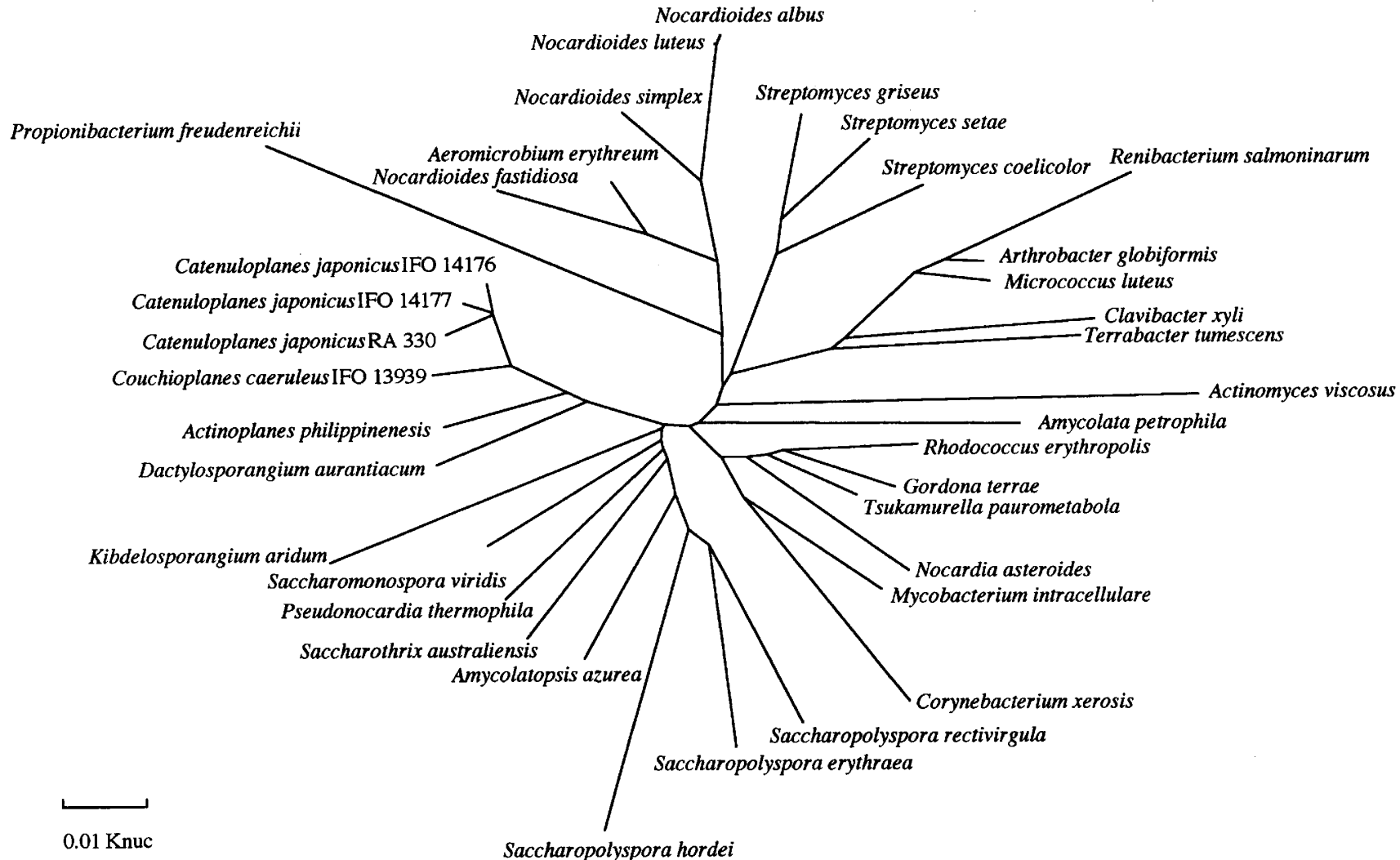

FIG. 4. Unrooted phylogenetic tree showing the relationships among Couchioplanes, Actinoplanes, Dactylosporangium, and Catenuloplanes species and related actinomycetes.

TABLE 8. Differential characteristics of the genus Couchioplanes and related actinomycete genera ${ }^{a}$

\begin{tabular}{|c|c|c|c|c|c|c|c|c|c|c|}
\hline Genus & $\begin{array}{l}\text { Aerial } \\
\text { mycelia }\end{array}$ & $\begin{array}{c}\text { Motility of } \\
\text { arthro- } \\
\text { spores }\end{array}$ & $\begin{array}{l}\text { Sporan- } \\
\text { gium } \\
\text { formation }\end{array}$ & $\begin{array}{l}\text { Cell wall } \\
\text { type }^{b}\end{array}$ & $\begin{array}{l}\text { Pepti- } \\
\text { doglycan } \\
\text { type }^{c}\end{array}$ & $\begin{array}{l}\text { Glycolyl } \\
\text { test }\end{array}$ & Major menaquinone(s) & $\begin{array}{l}\text { Phospho- } \\
\text { lipid }^{d y p e}\end{array}$ & $\begin{array}{l}\text { Fatty acid } \\
\text { type }^{e}\end{array}$ & $\begin{array}{l}\text { Whole-cell } \\
\text { sugar(s) }\end{array}$ \\
\hline Couchioplanes & $t^{f}$ & + & - & VI & $\mathrm{ND}^{g}$ & Glycolyl & MK-9 $\left(\mathrm{H}_{4}\right)$ & PII & $2 c$ & Xyl, Ara, Gal \\
\hline Actinoplanes & - & - & + & II & $\mathrm{A} 1 \gamma$ & Glycolyl & MK-9 $\left(\mathrm{H}_{4}\right)$, MK-9 $\left(\mathrm{H}_{6}\right)$ & PII & $2 \mathrm{c}$ & Xyl, Ara, Gal \\
\hline Catenuloplanes & + & + & - & VI & ND & Glycolyl & MK-9 $\left(\mathrm{H}_{8}\right)$, MK-10 $\left(\mathrm{H}_{8}\right)$ & PIII & $1 \mathrm{a}$ & Xyl \\
\hline Dactylosporangium & - & - & + & II & $\mathrm{A} 1 \gamma$ & Glycolyl & MK-9 $\left(\mathrm{H}_{8}\right)$, MK- $9\left(\mathrm{H}_{6}\right)$ & PII & $2 d$ & Xyl, Ara \\
\hline Pilimelia & - & - & + & II & $\mathrm{A} 1 \gamma$ & Acetyl & MK-9 $\left(\mathrm{H}_{2}\right)$, MK-9 $\left(\mathrm{H}_{4}\right)$ & PII & $2 b$ & Xyl, Ara \\
\hline Micromonospora & - & - & - & II & $\mathrm{A} 1 \gamma$ & Glycolyl & $\begin{array}{l}\text { MK-10 }\left(\mathrm{H}_{4}\right), \text { MK-10 }\left(\mathrm{H}_{6}\right) \\
\text { MK-9 }\left(\mathrm{H}_{4}\right), \text { MK-9 }\left(\mathrm{H}_{6}\right)\end{array}$ & PII & $3 b$ & Xyl, Ara \\
\hline Cellulomonas & - & - & - & VI & & Acetyl & MK-9(H $\left(\mathrm{H}_{4}\right)$ & PV & $2 b$ & Gal \\
\hline Promicromonospora & + & - & - & VI & & ND & MK-9 $\left(\mathrm{H}_{4}\right)$ & PV & $2 \mathrm{~b}$ & Gal \\
\hline Jonesia & - & - & - & VI & & ND & MK-9 & PV & $2 b$ & Gal \\
\hline
\end{tabular}

${ }^{a}$ Data from references $17,22,24,26,28,29$, and 31 .

${ }^{b}$ According to the classification of Lechevalier and Lechevalier (14).

${ }^{c}$ According to the classification of Schleifer and Kandler (22).

${ }^{a}$ According to the classification of Hasegawa et al. (6).

${ }^{e}$ According to the classification of Kroppenstedt (13).

${ }^{f}+$, present; - , absent.

${ }^{g} \mathrm{ND}$, not determined. 
TABLE 9. Differential characteristics of Couchioplanes caeruleus subspecies

\begin{tabular}{|c|c|c|c|c|c|c|}
\hline \multirow{2}{*}{ Organism } & \multicolumn{2}{|c|}{ Utilization of: } & \multicolumn{3}{|c|}{ Production of pigments on: } & \multirow{2}{*}{$\begin{array}{l}\text { Growth in } \\
2 \% \mathrm{NaCl}\end{array}$} \\
\hline & Rhamnose & Mannitol & $\begin{array}{c}\text { Yeast extract-malt } \\
\text { extract agar }\end{array}$ & $\begin{array}{c}\text { Glycerol- } \\
\text { asparagine agar }\end{array}$ & $\begin{array}{c}\text { Glucose- } \\
\text { asparagine agar }\end{array}$ & \\
\hline Couchioplanes caeruleus subsp. caeruleus & $+{ }^{a}$ & + & - & + & + & - \\
\hline Couchioplanes caeruleus subsp. azureus & - & \pm & + & - & - & + \\
\hline
\end{tabular}

${ }^{a}+$, positive; - , negative; \pm , weakly positive.

\section{ACKNOWLEDGMENTS}

We thank Yoshinobu Kaneko for help with 16S rRNA sequencing and Masao Takeuchi for his encouragement and support.

This research was supported by Grant-in-Aid for Co-operative Research 03304017 from the Ministry of Education, Science and Culture of Japan.

\section{REFERENCES}

1. Brosius, J., J. L. Palmer, J. P. Kennedy, and H. F. Noller. 1978. Complete nucleotide sequence of a 16S ribosomal RNA gene from Escherichia coli. Proc. Natl. Acad. Sci. USA 75:4801-4805.

2. Celmer, W. D., W. P. Cullen, C. E. Moppet, J. B. Routien, R. Shibakawa, and J. Tone. July 1977 . U.S. Patent 4,038,383.

2a.Container Corporation of America. 1958. Color harmony manual, 4 th ed. Container Corporation of America, Chicago.

3. Ezaki, T., Y. Hashimoto, and E. Yabuuchi. 1989. Fluorometric deoxyribonucleic acid-deoxyribonucleic acid hybridization in microdilution wells as an alternative to membrane filter hybridization in which radioisotopes are used to determine genetic relatedness among bacterial strains. Int. J. Syst. Bacteriol. 39:224-229.

4. Goodfellow, M., L. J. Stanton, K. E. Simpson, and D. E. Minnikin. 1990. Numerical and chemical classification of Actinoplanes and some related actinomycetes. J. Gen. Microbiol, 136:19-36.

5. Harper, J. J., and G. H. G. Davis. 1979. Two-dimensional thinlayer chromatography for amino acid analysis of bacterial cell walls. Int. J. Syst. Bacteriol. 29:56-58.

6. Hasegawa, T., M. P. Lechevalier, and M. P. Lechevalier. 1979. Phospholipid composition of motile actinomycetes. J. Gen. Appl. Microbiol. 25:209-213.

7. Hayakawa, M., and H. Nonomura. 1987. Humic acid-vitamin agar, a new medium for selective isolation of soil actinomycetes. $\mathrm{J}$. Ferment. Technol. 65:501-509.

8. Higgins, D. R., A. J. Bleasby, and R. Fuchs. 1992. Clustal V: improved software for multiple sequence alignment. CABIOS 8:189-190.

9. Horan, A. C., and B. Brodsky. 1986. Actinoplanes caeruleus sp. nov., a blue-pigmented species of the genus Actinoplanes. Int. J. Syst. Bacteriol. 36:187-191.

10. Ina, Y. 1991. Molecular evolutionary analysis system for DNA and amino acid sequences (ODEN), version 1.1. DNA Data Bank of Japan, DNA Research Center, National Institute of Genetics, Mishima, Japan.

11. Kandler, O., and H. König. 1978. Chemical composition of the peptidoglycan-free cell walls of methanogenic bacteria. Arch. Microbiol. 118:141-152.

12. Kimura, M. 1980. A simple method for estimating evolutionary rates of base substitutions through comparative studies of nucleotide sequences. J. Mol. Evol. 16:111-120.

13. Kroppenstedt, R. M. 1985 . Fatty acid and menaquinone analysis of actinomycetes and related organisms, p. 173-199. In M. Goodfellow and D. E. Minnikin (ed.), Chemical methods in bacterial systematics. Academic Press, Ltd., London.

14. Lechevalier, M. P., and H. A. Lechevalier. 1970. Chemical composition as a criterion in the classification of aerobic actinomycetes. Int. J. Syst. Bacteriol. 20:435-443.
15. Mesbah, M., U. Premachandran, and W. B. Whitman. 1989. Precise measurement of the $\mathrm{G}+\mathrm{C}$ content of deoxyribonucleic acid by high-performance liquid chromatography. Int. J. Syst. Bacteriol. 39:159-167.

16. Mikami, H., and Y. Ishida. 1983. Post-column fluorometric detection of reducing sugars in high-performance liquid chromatography using arginine. Bunseki Kagaku 32:207-210.

17. Minnikin, D. E., L. Alshamaony, and M. Goodfellow. 1975. Differentiation of Mycobacterium, Nocardia and related taxa by thin-layer chromatographic analysis of whole-organism methanolysates. J. Gen. Microbiol. 88:200-204.

18. Minnikin, D. E., M. D. Collins, and M. Goodfellow. 1975. Fatty acid and polar lipid composition in the classification of Cellulomonas, Oerskovia and related taxa. J. Appl. Bacteriol. 47:87-95.

19. Saiki, R. K., D. H. Gelfand, S. Stoffe, S. J. Scharf, R. Higuchi, G. T. Horn, K. B. Mullis, and A. Erlich. 1988. Primer-directed enzymatic amplification of DNA with a thermostable DNA polymerase. Science 239:487-491.

20. Saito, H., and K. Miura. 1963. Preparation of transforming deoxyribonucleic acid by phenol treatment. Biochim. Biophys. Acta 72:619-629.

21. Saitou, N., and M. Nei. 1987. The neighbor-joining method: a new method for reconstructing phylogenetic trees. Mol. Biol. Evol. 4:406-425.

22. Schleifer, K. H., and O. Kandler. 1972. Peptidoglycan types of bacterial cell walls and their taxonomic implications. Bacteriol. Rev. 36:407-477.

23. Shirling, E. B., and D. Gottlieb. 1966. Methods for characterization of Streptomyces species. Int. J. Syst. Bacteriol. 16:313-340.

24. Stackebrandt, E., and R. M. Kroppenstedt. 1987. Union of the genera Actinoplanes Couch, Ampullariella Couch, and Amorphosporangium Couch in a redefined genus Actinoplanes. Syst. Appl. Microbiol. 9:110-114.

25. Stackebrandt, E., W. Ludwig, E. Seewaldt, and K. H. Schleifer. 1983. Phylogeny of spore-forming members of the order Actinomycetales. Int. J. Syst. Bacteriol. 33:173-180.

26. Suzuki, K., and K. Komogata. 1983. Taxonomic significance of cellular fatty acid composition in some coryneform bacteria. Int. J. Syst. Bacteriol. 33:188-193.

27. Tille, D., R. Vettermann, and H. Prauser. 1982. DNA:DNA reassociation between DNAs of actinoplanetes and related genera, poster session. Abstr. 5th Int. Symp. Actinomycetes Biol.

28. Uchida, K., and K. Aida. 1977. Acyl type of bacterial cell wall: its simple identification by colorimetric method. J. Gen. Appl. Microbiol. 23:249-260.

29. Vobis, G. 1989. Section 28. Actinoplanetes, p. 2418. In S. T. Williams, M. E. Sharpe, and J. G. Holt (ed.), Bergey's manual of systematic bacteriology, vol. 4. The Williams \& Wilkins Co., Baltimore.

30. Wako Pure Chemical Industries, Ltd. 1989. Technical note for the system of PTC-amino acid analysis. Wako Pure Chemical Industries, Ltd., Osaka, Japan. (In Japanese.)

31. Yokota, A., T. Tamura, T. Hasegawa, and L. H. Huang. 1993. A new genus of the order Actinomycetales: Catenuloplanes japonicus gen. nov., sp. nov. Int. J. Syst. Bacteriol. 43:805-812. 